\title{
Bringing the Outside In: Somaliland, statebuilding and dual hybridity
}

Rebecca Richards

Lancaster University

Department of Politics, Philosophy and Religion

Lancaster, LA1 4YL

drrebeccarichards@gmail.com

+44 (0) 7815890199

\section{Author Bio:}

Rebecca Richards is a Research Fellow with the Richardson Institute at Lancaster University. She has also lectured at the University of Bristol, the University of East Anglia, the University of the West of England, and was a Research Fellow at the Somaliland Academy for Peace and Development in Hargeisa. Her research focuses on critical understandings of technocratic statebuilding and conceptualizations of the state. She has also published on the process of postconflict statebuilding in Somaliland and is the author of Understanding Statebuilding: Traditional Governance and the Modern State in Somaliland (Ashgate 2014). 


\begin{abstract}
:
International norms of what it means to be a state dictate domestic policy within developing and unrecognised states but must co-exist with internal demands. With a mutual dependence between internal and external considerations and, indeed, legitimacy, at the fore of Somaliland's statebuilding project and its stability, it is a useful study in achieving 'success' in statebuilding and in what success can mean in bringing together internal and external demands. This article examines the impact of the hybrid inclusion of traditional authority in the central democratic government as the marriage between internal and external demands. This article argues that the Somaliland state is successful because it is a flexible process rather than a project; a process that reflects the demands and expectations of society, an aspect that is often absent in statebuilding projects.
\end{abstract}

\title{
Keywords:
}

statebuilding, Somaliland, hybrid governance, traditional authority, liberal governance, unrecognised states 


\section{Bringing the Outside In: Somaliland, statebuilding and dual hybridity}

International norms of what it means to be a state dictate domestic policy within developing and unrecognised states but must co-exist with internal demands. With a mutual dependence between internal and external considerations and, indeed, legitimacy, at the fore of Somaliland's statebuilding project and its stability, it is a useful study in achieving 'success' in statebuilding and in what success can mean in bringing together internal and external demands. This article examines the impact of the hybrid inclusion of traditional authority in the central democratic government as the marriage between internal and external demands. This article argues that the Somaliland state is successful because it is a flexible process rather than a project; a process that reflects the demands and expectations of society, an aspect that is often absent in statebuilding projects.

Keywords: statebuilding, Somaliland, hybrid governance, traditional authority, liberal governance, unrecognised states

The 1991 failure and collapse of the state in Somalia ushered in what was to become a long-term and largely unsuccessful effort aimed at internationally driven post-conflict statebuilding. Despite persistent failures the international community and Somalia's neighbours continue their endeavours aimed at building a stable, unified and accountable Somalia. However, as Spears (2004, 179-80) notes, 'in a few cases [of state failure or collapse], the breakdown of large, arbitrary state units has given way to more coherent and viable (though not always more benevolent) political entities.' In Somalia, this breakdown was immediately apparent and it continues to take place. Although emerging political entities within Somalia are not always lasting or stable, pockets of locally created governance have emerged, providing social and physical stability and security to the people. In the northeast province of Puntland, a long-standing regional government offers basic services and security to the population. And in the northwest territory of Somaliland, the most organised and developed of these, a new 'state' that exhibits what has so far eluded the south is emerging, and an extraordinary project of domestically-led statebuilding is taking place within the larger failure of Somalia. ${ }^{1}$

Throughout the literature on failed states and that of statebuilding, the on-going project in Somalia is a frequent point of reference. Within these studies the existence of an independent Somaliland has 
widely been seen as problematic for the long-standing goal of re-establishing a government able to exercise its power throughout the entirety of Somalia. Despite its 1991 declaration of independence, the insistence on the territorial integrity of Somalia coming from the West as well as strongly from the African Union ensures that Somaliland's stability remains in the context of stability in greater Somalia. Although Somaliland is gaining increasing academic attention, it still remains an underresearched area. In the realm of policy, despite increasing external engagement with the territory, much of this takes place under the guise of Somalia-wide projects. The case of an independent Somaliland therefore remains conspicuously absent from much of the statebuilding policy, practice and literature.

However, as an unrecognised state seeking international recognition of sovereign statehood and largely removed from the intrusive and expensive statebuilding efforts in the south of Somalia, Somaliland's aspirations and its relative isolation come together in an extraordinary project of statebuilding. Whilst initial claims for recognition were rooted in law and invoked Somaliland's brief standing as an independent state following British colonial withdrawal in 1960 (Lewis, 2002; Bradbury, 2008; Drysdale, 2000), the evolution of Somaliland's strategy for recognition in many ways reflects the evolution of what is expected of states. Thus, today's calls for recognition are grounded in claims of worthiness and acceptableness; Somaliland meets the standards of statehood and therefore 'deserves' to be a state. Worthiness is a common claim amongst unrecognised states (see Caspersen, 2012; Caspersen and Stansfield, 2011; Kolsto, 2006). However, the politics surrounding recognition and statehood are complex (see Daase et. al., 2015) and as Caspersen and Stansfield $(2011,6)$ note, the chances for recognition are remote. Worthiness alone is unlikely to garner a political entity sovereign statehood status. Despite this, the perceived need to exhibit acceptable statehood is an important factor within the statebuilding process in unrecognised states and with the resulting 'state'. However, unlike with externally-led statebuilding, domestically-led processes must depend on being 'propped up' from within. Indeed, a defining characteristic of statebuilding in these entities is balancing external expectations of statehood with domestic demands; it is a process propelled by the perceived need to be 'worthy' or acceptable yet at the same time is dependent upon continued domestic support necessary to sustain a domestically-propelled and sustained process (Richards, 2014; Caspersen, 2012; Kolsto, 2006). Out of necessity, statebuilding in unrecognised states, including in Somaliland, is a balance between external and internal legitimacy.

Statebuilding is more than institution building; it is also socio-political change that creates, sustains and legitimises a separate political entity, both to the international community and to the domestic 
audience (see Call, 2008; Sisk, 2013). Because of this, analytical examinations of statebuilding must go beyond the technocratic or the institutional to also include the socio-political processes involved. Technocratic studies and political histories of Somaliland exist (Lewis, 2002; Bradbury, 2008; Renders, 2012), but academia is only beginning to analytically engage with the whole of the statebuilding process that continues to take place. The Somaliland state is a hybrid one not only in that it brings together traditional ${ }^{2}$ and modern forms of governance, but within this it also balances external demands and internal necessities. The former is widely discussed in the literature, but the latter is often overlooked. However, this tandem form of hybridity is one that has become a vital component of stability in the 'state' and one that serves to legitimise the project both externally, and, crucially for the unrecognised state, internally. With a mutual dependence between internal and external considerations and legitimacy at the fore of statebuilding in Somaliland, the processes taking place are a useful study in not only 'success' in statebuilding, but also in what success can mean.

Guided by both external expectations and internal necessities, Somaliland has created the apparent antithesis to its parent-state, Somalia. Two questions rise from this, however: how did it do it, and what can it tell us about the process of successful statebuilding? Whilst this article does not attempt to provide a comprehensive answer, these questions form the basis here. This article first establishes a framework of external expectations of modern statehood before examining the dual hybridity in Somaliland. The article examines the function and impact of the marriage between these bifurcated demands, needs and expectations in the wider project in Somaliland before drawing broader conclusions related to wider conceptions of statebuilding. As the statebuilding project in Somaliland has spanned more than twenty years and is undeniably a complex and multidimensional process, a comprehensive overview cannot be given here. ${ }^{3}$ Because of this, this article will focus on one area where the dual hybridity is present: Somaliland's legislature.

\section{Deciphering the External 'Ideal'}

Despite scholarly arguments against it, the long-held insistence on an externally-led project of creating a central democratic state in Somalia reflects the trend of promulgating a universally applied style of state (see Menkhaus, 2007; Bryden, 1999; Chatham House, 2012; Dowden, 2011; Bruton, 2010; Halden, 2008; Pham, 2011). The response to what are seen as financial, political social and security concerns is a prescribed 'one size fits all' approach (see Chesterman et al., 2005, 4) to modern statehood; an approach rooted in liberal understandings of what the state should be. Whilst

the Weberian territorial control and monopoly of force within that territory invariably remain essential components of modern statehood, the evolution of what it means to be a 'state' and an 
increasingly emphasised link between good governance and developmental success has shifted focus to what is occurring within the state rather than merely emphasising the existence of a state and the protection of its borders (Brownlie, 1998; Jackson, 1990). Rotberg (2003, 3) exemplifies this succinctly in identification of key political goods that hierarchically are used as valid tools of judgment and evaluation. Physical and human security are at the top of the list, but amongst the vital components are liberal expectations pertaining to democratisation, participation, social provision and even the promotion of civil society. The normative values underpinning what it means to be 'a state' centre on performance markers or benchmarks of 'acceptable' statehood based on the ideals of the Western liberal state (see Adamson, 2006; Finnemore, 1996; Finnemore and Sikkink, 1998). Empirical statehood is needed for 'successful' statehood, and empirical performance is assessed or measured against what is expected or acceptable within the normative framework of statehood. Success and acceptableness, therefore, is determined in a way that presumably legitimises the state externally with the assumption that internal legitimacy will follow. The proliferation of these expectations of statehood is at the centre of statebuilding policies.

As noted by Chandler $(2010,1)$, the frameworks of good governance that underpin state-building policies 'are seen as a "silver bullet" capable of assisting states in coping with the problems of our complex globalized world'. The successful - even 'ideal' - state to be achieved through statebuilding is one in which political, economic and security threats are eliminated and the practices, policies and structures of the state are familiar and easily accessible to the international community, particularly the West. It does not reflect an already existing state structure, but rather comprises a wish list of sorts; it is a composition of factors that together would make an acceptable state not only for security, but also for political and economic relationships in the international community. The 'silver bullet', therefore, is less aimed at reflecting methods or mechanisms of governance in the targeted area than it is at reproducing Western forms of liberal governance deemed worthy, acceptable or safe. Although the ideal state is more accurately an ideological reflection of desires, this rubric of statehood is exhibited in policy as the desired outcome of interventionist actions. In statebuilding, the result of this is the implementation of a uniform model of statehood as a preferred style of state, and statebuilding projects become more a technocratic exercise than a creation, or fostering, of a political system (see Ghani and Lockhart, 2005; Ghani and Lockhart, 2008; Fukuyama, 2006; Dobbins et al., 2003; Dobbins et al., 2005). Autonomy is removed from the state in question and an environment is created in which alternatives to or deviations from this blueprint of statehood and the path through which to reach it are rarely trusted, regardless of any success or compliance that may be exhibited. Consequently, such norms of what it means to be a state can also direct domestic statebuilding or 
reform policy. External expectations and normative frameworks become a means of intervention themselves, even when direct intervention is absent: The normative model becomes an actor in and of itself (Richards, 2012).

The concern here, however, is this uniform perception and approach to crafting states. It is not that the underlying intention is flawed - it is difficult to argue against the liberal intention of peace, security and prosperity. However, the path through which to achieve this is problematic, not least but in its ideological and structural rigidity. Given the limited success of past statebuilding projects and the significant obstacles facing current ones, one must question whether the 'silver bullet' approach is preferable to fostering internally legitimate political authority that first reflects domestic necessities (see Milliken, 2003; Gourevitch, 2004; Paris and Sisk, 2009; Chandler, 2010; Richards, 2012). In other words, are ideological expectations of outcome resulting in a deficient process? In examining alternative forms of statebuilding, it is possible to understand and also critique the expectations for modern statebuilding projects and processes. An ideal starting point for this is Somaliland. On empirical grounds Somaliland 'fulfils the principle criteria for statehood' (Bryden, 2003). By all appearances it is an 'acceptable' state, albeit one that lacks international recognition of sovereignty. However, Somaliland exhibits a deviation from the liberal blueprint and liberal path both in its statebuilding process and it the resulting central hybridity. It is this deviation and the resulting flexibility that provides significant analytical value in the context of statebuilding.

\section{Hybrid Somaliland}

On 18 May 1991, the Republic of Somaliland formally declared its independence from Somalia and began the processes of reconciliation and political construction within the borders of the former British Protectorate of Somaliland. For Somaliland, the nearly decade-long Somalia civil war was fought primarily by the Somali National Movement (SNM), a liberation movement based in the northwest and rooted primarily in the territory's dominant Isaaq clan (Samatar, 1997; Bradbury, 1997). As Bradbury (2008, 60-61) maintains, 'the restoration of stability in Somaliland owes much to the existence of the SNM and the history of its struggle against the Siyad Barre regime'. The SNM was established as a political movement with the aim of toppling Barre and restructuring a Somaliawide democratic government that would be inclusive of and based on the clan system. Throughout its existence, the SNM maintained that the clan system was a building block of government in Somalia as it 'lay at the root of political stability, social cohesion and economic activity' (Bradbury, 1997, 21; WSP International, 2005). As Lewis notes in his authoritative work on the subject, the original aim of the SNM was to forge a federal democratic system rooted in the Somali system of community 
governance (beel); indeed, the first SNM constitution, created in 1981, mandated that clan units should be respected in any new government and that cooperation between the clans should be based on customary law (xeer) rather than through government mandates or force (Lewis, 1994; Lewis, 2002) The constitution also gave clan elders an important role as grassroots decision makers within the movement. With this recognition of the centrality and importance of the clan and clan elders in politics, the SNM proposed combining 'the advantages of Somali democracy and egalitarianism with the benefits of modern national government' (SNM press release as cited in Lewis, 1994, 199). In addition to the anticipation of effective, fair and peaceful governance in Somalia, by incorporating the clan the SNM hoped to end destructive clannism, a recurring problem in post-colonial Somalia. As Drysdale $(2000,160)$ notes, by placing primacy in the clan as a useful, necessary and stabilising element in a new government rather than a divisive political factor, the by 1991 the SNM was successful in reversing attitudes against clannism that had been prevalent under previous governments.

The SNM's plan for centrality of the clan in a decentralised federal system would have effectively placed the majority of Somaliland under Isaaq rule and the majority of Isaaq under Somaliland rule, an idealistic situation of self-governance for the predominant clan in the territory. However, the reality of dependence on wider clan structures and governance came to the fore long before the fall of Siad Barre. In 1981 the then almost exclusively Isaaq SNM moved its base of operations to Ethiopia where the movement gained assistance from the Ethiopian government and rooted its support in the Isaaq in the country. During its time outside of Somaliland, the involvement of clan leadership had been important for negotiating support within ex-pat communities. With the move to Ethiopia, the clan elders were tasked with a more active role and thus became entrenched in the operations of the movement. The first SNM council of elders, referred to as a guurti, was convened in 1982 to reconcile between the SNM and an Ethiopian government that had a wary view of the Somali population in the country. Historically an ad hoc body that was considered the highest form of political authority within the non-hierarchical clan system, the guurti is a mechanism of clan governance used to resolve differences between the clans or to unite the clans in times of crisis or war, as well as being the primary actor in establishing social patterns, forming common cultural policy and forging trade and other economic relations (Lewis and Farah, 1997; Shivakumar, 2003). For the SNM, though, the first guurti was used in a quasi-diplomatic manner, acting as a mediating link between the movement and the Ethiopian government. When asked why the elders were tasked with this rather than a political or military figure, Hassan Issa, the man in charge of convening this guurti, simply replied, 'it's Africa' ${ }^{4}$ The trust associated with traditional figures was used to invoke 
respect; an invocation that continued throughout the period of the SNM. The leadership of both the political and military wings of the movement utilised the pervasive Somali clan, specifically trusted clan elders, as a political and strategic tool to garner the support needed for its campaign. When the Ethiopian government revoked its support in 1987, the SNM was forced to incorporate all the Somaliland clans as the elders became the key 'middleman' between the movement and the population for much needed logistical and ideational support (Lewis, 2002; Bradbury, 2008; Richards 2014; Renders 2012). As one former SNM member stated, 'everything we had - men, vehicles, clothes, food, money - everything came from the clans'. ${ }^{5}$ The utilisation and centrality of the clan in the socio-political processes taking place integral for the liberation movement, and this continued for the political leaders who embarked on the process of creating a post-conflict Somaliland state. ${ }^{6}$ As noted by Bradbury (2008) in his seminal work on building the Somaliland state, the clan became not only a component of the government but also a vital actor in the reconciliation and post-conflict statebuilding process.

As Renders (2012) identifies in her history of this period, complex political occurrences and relationships shaped and defined the Somaliland state during this time; relationships that have impacted upon political developments to this day. Indeed, as also chronicled by Bradbury (2008), the first years of Somaliland's independent era were turbulent, with a return to conflict in 1995. However, in the immediate post-1991 period violence was kept to a minimum. Most scholars as well as actors within Somaliland attribute this to the reconciliation actions of the SNM, particularly in allowing for a reconciliation process led by clan elders rather than asserting its authority in the territory through force. Indeed, the SNM's policy of 'peaceful co-existence among the northern clans and the decision to break with Somalia created an environment that was relatively stable' (Bradbury, 2010, 125). With the SNM in the position of victor, the process of negotiating peace between various factions was the only avenue taken. Although never fully winning over all actors in the territory, this reconciliation and (re)construction process, characterised by a succession of clan-led national reconciliation conferences led by clan elders and involving actors from all sectors of the Somaliland community (see Bradbury, 2008; Lewis, 2002; Walls, 2009; Walls 2008; Renders 2012), laid the foundations of and set the stage for the process of creating a government and state in Somaliland; a process that continues to this day.

The importance of the clan was recognised within the structure and the function of the government, however the clan as a mechanism of governance co-exists with a modern democratic institutions and practices, creating a government that is a hybrid between traditional and modern democratic in both 
structure and practice (Walls and Kibble, 2010). Traditionally, 'peacemaking' clan elders hold an immeasurable amount of political and social power and influence in Somali society, ${ }^{7}$ even with the existence of a central government (Lewis, 2002). The centrality of these familiar and trusted peacemakers in the processes of reconciliation and state-making inarguably facilitated the peaceful and stable environment necessary for the implementation of the drastic reforms brought about with the creation of the new central government and a new state. The stabilising influence of the elders initially utilised during the civil war was continued in the post-conflict period with the reassurance, leadership and decision-making of the elders during the reconciliation and formative statebuilding processes. This leadership and familiarity was institutionalised in the upper house of parliament in the new transitional central government. Indeed, many of the elders participant in the SNM's guurti became members of the new House of Elders, the Golaha Guurtidda, or Guurti, as it is called in Somaliland. ${ }^{8}$ Whilst institutionalised as a legislative body, the Guurti's primary role and function in the transitional government was that of mediator, arbiter facilitator and legitimiser, roles in which it held immeasurable power. In the elder-led national reconciliation conferences, the first institutional steps of statebuilding took place. The elders of the conferences, many of whom had been part of the SNM guurti, also appointed the SNM-led transitional government in 1991 as well as the first civilian government in 1993. In essence, the state emerged from the clan-led conferences. Sovereignty was passed from the clan to political leaders, thereby ensuring that the government garnered its legitimacy from the clans. The provisional constitution was considered customary law (xeer), which bound the Somaliland clans to uphold and fulfil it. Further, throughout this period, traditional mechanisms of governance acted to bind society together and the clan continued to exist within the government structure itself, with customary law underpinning the constitution and the elders of the now institutional Guurti residing not only within but also above the government in its role as advisor and mediator. With the ratification of the permanent Somaliland constitution in 2001 - a document again considered customary law - the placement of the clan and the marriage between traditional and modern governance were maintained and formalised. The clan and clan governance is entwined throughout the institutions and the practices of the state.

Somaliland's hybridity is generally discussed in terms of the relationship between the traditional and the modern in the forming government (see, for example, Renders 2012; Hohne 2013; Walls and Kibble 2010). However, it does not stop with this; it has dual faceted hybridity. It is inclusive of both familiar traditional governance and modern democratic government, but it also reflects hybridity in balancing domestic needs and external demands in the statebuilding process and the state. There has been little external intervention in the Somaliland project, meaning it has been and continues to be a 
predominantly self-led endeavour that has been domestically maintained and supported since 1991. However, much of the motivation behind the continuation of the process is recognition of sovereignty; a goal which actors within Somaliland acutely and openly acknowledge necessitates the meeting of external demands. In Somaliland, one set of demands cannot be met without also meeting the other; the relationship between the internal and external is one of mutual dependency.

Although international actors such as the EU have engaged politically through actions such as supporting elections in Somaliland, most external intervention has been in the way of social provision, and almost all external intervention has taken place under the guise of wider Somalia projects. Direct external intervention in the political process itself primarily comes from the Somaliland Diaspora through financial and political remittances. The process of statebuilding in is a top-down process, but it comes from within and it is sustained from within the Somaliland community. Whilst the government itself is weak when compared to Western expectations, it exists not despite opposition, but largely, and tellingly, because of it. Political opposition is accepted within Somaliland, and negotiating solutions to obstacles or addressing challenges raised both from within and outside of government has become a feature of the on-going process. Like in other unrecognised states, this is vital in Somaliland as a loss of domestic support would threaten the continuation of the state's existence. In addition, maintaining peace and stability is essential to the externally directed strategy for recognition of sovereignty. The Somaliland state cannot suppress domestic opposition or compel domestic acceptance through force or with an iron fist; it must maintain its domestic support through avenues in compliance with external expectations. The relatively stable existence of the state since 1991 demonstrates an element of success in maintaining this domestic legitimacy. Maintaining domestic legitimacy whilst simultaneously complying with the demands of external legitimacy is a balance that Somaliland continues to negotiate and maintain as the statebuilding process continues.

Like all states, Somaliland is not perfect in practice. The picture being presented by the government, though, is a state in compliance with the normative values and practices surrounding the perception of the 'acceptable' state. ${ }^{9}$ Whilst many of these standards are met, many of the successes and processes of the Somaliland state would not fit within the mould constructed by the norms of the 'acceptable' state and therefore may not be immediately recognisable as facilitators of stability or political development. In Somaliland the state is arguably a political process rather than a governing entity and the government is a tangible reflection of this process; the state in Somaliland is a complexity of motivations and ideas embodied by the institutions. Much of what is driving the Somaliland project and process is not only a desire for peace and stability, but also a desire to be 
separate from the chaotic south. The realisation of this independence depends on international recognition of sovereignty, and this drive for recognition underpins many of the political processes, developments and occurrences in Somaliland today, including the style and functions of the government. ${ }^{10}$ The modern democratic element of the government is seen by many as necessary to obtain recognition of sovereignty or, at the very least, financial assistance, investment and development. Thus, with the maintenance of peace and the stability of the government seen as vital to the survival, or even birth, of the state, despite its weakness and arguable distance from the population, for many Somalilanders the future of the potential for Somaliland rests with the survival of the government itself. This complex dual hybridity - the mutual dependence between internal and external and between traditional and modern - defines the Somaliland state (Richards, 2014). The complexity of this need for continued stability and the utilisation of the clan to balance internal and external demands makes the role of the clan in the central government and the statebuilding process one that cannot be overlooked.

\section{Stabilisation, statebuilding and the clan}

For Somali society, '[t]he clan is everything. It is the basis of all. Social, economic, political, all'. ${ }^{11}$ As Bradbury (1997, 4; 2008, 18) asserts, '[c]ollective action through kinship provides physical, political and economic security,' it 'remains an important feature of Somali social, political and economic life.' Although factors such as the emergence of a state, urbanisation, migration and the impacts of colonial or government policies have altered and lessened the impact of the clan system, (Samatar, 1989) as indicated by many urban elite within Somaliland clan structures there were largely maintained out of both opportunity and necessity, existing not in tandem with but in the gaps of the state. Once the state collapsed and 'peace and reconciliation were the most immediate need,' traditional and religious leaders once again 'organised themselves to fill the vacuum of no central authority' (Sweden, 2004, 175). As researcher Mohammed Hassan Ibrahim 'Gani' observes, when the state is weak, absent or violent the clan fills the gaps of social, economic, political and security provision typically managed by the state. ${ }^{12}$ Former vice president Hassan Issa maintains that as in the nomadic Somali tradition the only authority was the clan, it is 'natural' for traditional authority to reemerge outside the purview of the state in times of crisis or state weakness. ${ }^{13}$ During the early stages of statebuilding in Somaliland, the 'weak' state meant that the 'Guurti [was] everything' 14 The clan, even if muted, has been and continues to be an important tool of governance in Somaliland.

As early as 1982 SNM leadership invoked and utilised the clan body to serve the reconciliatory purpose of the traditional Somali elders as well as act as a mediator for the SNM; a mediator between 
the movement and external forces and between the movement and the people. The first SNM guurti was not the traditional ad-hoc, decentralised and democratic council of clan elders, but instead became a permanent political body within the movement; it became the Guurti. Throughout the fight against Barre, this creation was a continual presence, becoming increasingly vital as fight moved into Somaliland and the SNM was forced to garner support from non-Isaaq clans. Following the SNM's 'liberation' of Somaliland, the elders of the Guurti became a point of reassurance for the people during a very turbulent and uncertain period. Perceived as having no obvious political agenda, the elders were also looked to for leadership. Because of traditional associations, their position of trust and familiarity, their role within the liberation movement and because of opportunity, the postindependence Guurti 'came into their own, empowered by civil war and devastation'. ${ }^{15}$ Taking on the vital role of reconciliation in a war-torn society and 'based on the idea, the understanding, that in Somali culture elders always had a unique role', ${ }^{16}$ the body again acted as the mediator for the SNM, this time between the new government movement and the people. As the oldest member of the Guurti states, '[w]e were a ladder or a chair for independence...you can't initiate government with hostility in the community'. ${ }^{17}$ As Somaliland moved into the era of independence, the clan body became increasingly entrenched in the political structure and processes of the government. The firm institutionalisation of a form of guurti within the governing structure of the emerging state not only cemented its role in the political process in Somaliland, but also highlighted the trusted valued role of the elders in Somaliland governance.

The re-invention of the guurti as an institutionalised political also mediated between the old and the new, creating a backbone for the democratic desires of the SNM and later for the democratic necessity of the campaign for recognition. Of the body's early importance, Mohamed Said Gees states: '[t]he Guurti was the seed. It was the administration that the current administration was built on. Because of them, we have rule of law, order and a social system. They were absolutely necessary for statebuilding. ${ }^{18}$ Much of this is widely credited to the body's peacemaking and reconciliation roles. As a former commander of the SNM stated, 'clan problems couldn't be solved through democracy that no one knew. We needed the Guurti for this...the SNM guurti turned into the Somaliland Guurti and took on a reconciliation role. ${ }^{19}$ The importance of the council of elders in introducing democracy, though, is also recognised. Former Minister of Foreign Affairs Abdullahi Duale recognises that although necessary, democracy was unknown to the majority of the population of Somaliland and ' $[\mathrm{t}]$ eaching and introducing the democratic process itself was a huge challenge...We put the package together and sold it to the people. It's a miracle it happened. ${ }^{, 20}$ The Guurti served as an actor in this. As Haji Abdi Husein notes, '[t]he role being taken by the Guurti in 
this government is the same as its previous role...during the colonial era they interpreted the intentions and activities of the colonials, foreign rule...now that role is being exercised by the current Guurti. ${ }^{21}$ The SNM had observed that they could not 'jump from the lowest part of the ladder to the top; we needed the Guurti, and we needed them to make the clans share something. This was preferable to imposing democracy that no one knew'. ${ }^{22}$

Democracy had been an objective of the SNM from the start, and following 1991 democracy became intrinsically linked with the success of Somaliland's quest for recognition. In a 2000 speech President Egal openly linked democratic government with recognition, stating, '[w]e could only be accepted as a member of the world community if we move to a new stage of nationhood...The international community does not recognize congregations of clans, each remaining independently separate'(APD, 2005, 16). The clan institution continued to be an important component in the introduction of democracy. However, a shifting focus towards recognition with 'all other problems secondary' ${ }^{23}$ meant shifting for the Guurti, and the clans, too. This becomes more apparent as democracy becomes more realised in practice rather than maintained as a perception.

The unfamiliar 'Western' style of government was always balanced by the inclusion of and almost dependence on traditional governance, in both times of stability and in times of transition. Undoubtedly the institutionalisation of the mechanism of clan governance changed the nature of the traditional Council of Elders, making it a permanent fixture in the governing structure rather than an ad hoc body recalled in times of conflict or crisis, and making its members part of the central political process. However, the stabilising impact of the governance structure remains and is embodied in constitutionally defined roles and in symbolic roles. Together, these roles have formed the basis of the 'Somaliland spine' and have facilitated the introduction of the 'modern' state in Somaliland.

\section{Bridging the Gaps}

Although the clan is emerging as an institutional mechanism of government, it is not re-emerging uncontested as the sole authority, nor is it being empowered external to the state apparatus. Somaliland's leaders 'ex post facto accepted and partly legalised existing power-positions that had developed during the times of civil war, state-collapse and state reconstruction,' drawing upon the powerful position that clan elders held during these times of crisis as a component of the foundations for the state (Hohne, 2006, 17). In post-Barre Somaliland the formal institutionalisation of the position and role of these men assured that legitimising and stabilising clan authority would emerge 
within the state apparatus. The traditional authority that rose up during times of crisis and helped establish the foundations for the new state currently exists both within and alongside the central governing structure, creating a centralised and seemingly permanent amalgamation of state and clan.

Constitutionally, the Guurti is a legislative body with responsibilities for the maintenance of peace and security and for the protection of tradition, culture and religion. Whilst the House of Elders is a component of the modern state structure as the upper house of parliament, the Guurti is also the rooting of the clan that the SNM deemed necessary for the success of the government, and eventually democracy, in Somaliland. It is a permanent representation of the Somaliland clans in the government. As one member of the Guurti states, this inclusion of the clan ensures that the government in Somaliland 'matches [Somaliland] culture'. ${ }^{24}$ The Guurti is inextricably linked to both the state and the people through the common denominator of the pervasive clan. Because of this, the government institution is in a position where it is both a part of the state and society, as well as a bridge between the two, linking the state to society and society to the state and 'hold[ing] together the government, society and culture'. ${ }^{25}$ With the introduction of democratic practices in the government, the inclusion of the clan became a point of reassurance for a population that had very little, if any, experience of democracy. In a time of upheaval and transition, the Guurti was a familiar association in an otherwise unfamiliar system and Somaliland's leaders were able to utilise the clan to bridge the gap between the government project and the population. In its capacity both within and external to the state apparatus, the Guurti became a chain linking the familiar forms of governance (and protection) with the new. Because of the 'turbulent times' it was not possible to 'get rid of the old ways quickly'. ${ }^{26}$ The Guurti served as a tempering link that eased the creation of a central government in a territory that was understandably wary of centralised rule and helped facilitate steps towards democratisation. Even though the traditional guurti has been altered to fit its contemporary institutionalised role, the trusted clan association contributed to the Guurti's successes in maintaining peace, in obtaining popular support for the government and in aiding the introduction of democratic concepts and practices (Richards, 2012). The House of Elders not only links the government to the people but also helps ensure that 'Somaliland' is not lost in the process of building a modern government. Thus, in a more symbolic capacity, the inclusion of the clan authority in the central government serves to bridge the gaps in Somaliland's hybridity, linking the old and the new as well as the domestic and the external.

The role of the Guurti as a bridge extends beyond what its representation of the clan system in a democratic government. This role also extends into the mediation capacity of the elders, both 
practically and symbolically. The constitution (2001) grants the upper house the power to advise and oversee the government, alerting of any 'shortcomings of the administration of the Government'. Broad interpretations of these responsibilities ensured the Guurti's intended role as the mediating influence in Somaliland politics and the statebuilding process. ${ }^{27}$ Here the body acts in a quasijudicial manner that invokes the historic role of the ad hoc clan councils as the Guurti becomes the mediator within the government itself, working to resolve contestation within the government when it arises. The Guurti has repeatedly provided fora in which problems can be addressed and resolved during the statebuilding process. In these instances, the primary role of the Guurti has been to facilitate decision-making and conflict resolution through long-practiced Somali mechanisms (for a narrative description of these, see Lewis 2002). Although in smaller or more localised contests the elders themselves act as referees, on the larger national scale the role of mediator is one of presence or facilitation rather than active participation; it utilises the symbolic traditional and the practical mechanisms of clan governance. The continuing and complex internal-external placement of the Guurti both within and outside of the government makes the body a mediator within the government but also a bridge between social and political actors. The body's role has changed throughout the statebuilding process, but clan association and the advisory capacity of the Guurti have to date ensured its place as a body both within and suspended outside the government.

The Guurti has regularly exerted its role as mediator and advisor, most notably when changes in the composite membership of the government threaten stability or present challenges to the state. Following the 2003 presidential election in which an eighty vote margin separated the winner and the runner-up, the Guurti negotiated the concession of the runner-up candidate; this intervention was viewed by many as a politically neutral action carried out in the interest of maintaining stability in the first major test of democratic elections in the territory (Bradbury, 2008, 194). The result was a peaceful outcome, a continuation of the integrity of the government and the electoral process, and a smooth transition from an appointed to an elected presidency. The Guurti also exercised its role as mediator following the 2005 House of Representatives election when a potentially destabilising contention between the political parties over leadership of the house ensued. The Guurti intervened to resolve the issue, negotiating an agreement between all three parties that gave control of the house to a coalition of the opposition parties (Bradbury, 2008, 226-229). The Guurti is often looked to when an intra-governmental problem arises, and this quasi-judicial role has been invaluable in maintaining governmental stability during the statebuilding process. However, as the government continues to develop and 'modernise,' this role is being significantly tested, particularly in disputes pertaining to the Guurti itself or to its political interests. A 2006 dispute over the term length for the 
Guurti made this possibility all too apparent when the Guurti found itself in the middle of an intragovernmental dispute about itself, a dispute that was exacerbated by the Guurti's role in the lengthy postponement of presidential elections (see Richards, 2014; Renders, 2012; Hohne 2013; Walls 2009; SAPD 2012).

The 2006 self-extension crisis emphasised calls for reform. It is obvious that the Guurti is a political body; it is no longer the apolitical mechanism that it was meant to be. What is less clear, though, is has the politicisation of the body removed the practical and symbolic benefits stemming from its clan association? Some, including voices from outside the Somaliland community, raise accusations of corruption and co-option by a powerful executive and question the role of an unchecked powerful body within a modernising government (see Hoehne 2013; Terlinden and Renders 2011). Others recognise reform is inevitable and will come as needed and as part of the process (Walls and Kibble 2010). Still others maintain the Guurti is a distinguishing feature of the Somaliland state and vital to continued stability and growth (for more on these camps, see Richards 2014). The placement and purpose of the Guurti will change as the state itself changes, but that itself is part of the statebuilding process and its importance thus far in a domestically-led and legitimised statebuilding process should not be overlooked.

\section{Conclusions: Bringing the outside and the inside in}

Certainly, there is much more to the statebuilding process in Somaliland than solely the inclusion of the clan in central government; the ongoing process taking place in the territory, its successes and its obstacles cannot be reduced to just the inclusion of traditional authority (see, for example, Bradbury, 2008; Lindley, 2005; Walls, 2009; Renders 2012). Statebuilding is a highly political process, and as others such as Renders (2012) and Hoehne and Ibrahim (2014) have identified, statebuilding in Somaliland is not an exception. Indeed, even the purpose and placement of the Guurti can be debated, from viewing it as a politicised actor from the start (Renders 2012; Hoehne 2013) to questioning its inclusion in the institutional structure of the state primarily as a means to buy-off potential challenges to power (Richards 2010; 2014). However, despite hard-to-answer questions about intent, and bearing in mind the role of the clan is only one component of a complex process, conclusions from the inclusion of the traditional can be made that characterise the process more broadly and, in doing so, comment on the creation of a 'successful' state.

In June 2005 the World Bank published a report written by former minister Ahmed Mohamed Hashi which argued that traditional authority in the central government in Somaliland was a destabilising 
factor (2005). Hashi claimed that traditional authority had been irreversibly co-opted by corrupt political machines and that the 'traditional' itself has been damaged beyond repair. Thus, as long as traditional authority is included in the central government of Somaliland it will be plagued by the same clan struggles and warfare that characterise the political process in Somalia. Hashi has a point here: the members of the Guurti have become political actors concerned with their own position within the government rather than apolitical and selfless elders, and that has created obstacles for the state and the ongoing process of statebuilding. However, although this may be the case today it does not negate both the practical and symbolic impacts of the clan elders in the government and in the statebuilding process. It also certainly does not reflect the on-going process of statebuilding and political development in Somaliland, one that does question the role of the clan and the shifting balance between old and new, but does so through discussion and politics rather than confrontation and conflict (see Walls and Kibble, 2010; Richards 2009). Hashi highlights some hard truths, but he also underestimates the strength and flexibility of the political process in Somaliland; a resilient process that has negotiated, and continues to negotiate, significant obstacles in the ongoing statebuilding and democratisation processes.

However, the association made between traditional authority and instability is nothing new. In his work on the state, Max Weber (1967) identified the various stages through which a political organisation would pass before becoming a modern - what could be equated to today's 'acceptable' or 'successful' - state. Amongst these was rule by traditional leaders, but within statebuilding today these authorities carry the connotation primitiveness and of being the 'eternal yesterday.' (Weber, 1967; Shils, 1995; Shils, 2006). Viewed as unknown and unpredictable, the utilisation of traditional authorities in the state apparatus has been largely excluded from external discussion and policy regarding statebuilding, stabilisation and development. Indeed, if external intervention had guided the process in Somaliland, it has to be questioned whether the clan would have been allowed to play such an integral role in the foundation, stabilisation and continuation of the process, or whether it would have been excluded from the start as it was in Somalia. If viewed in Weberian terms, on its path to modernity Somaliland is passing through the stage of traditional leaders, and in doing so deviates from the short-cut path espoused in externally-led statebuilding.

Somaliland is a case in which going off-piste was essential in creating the stability necessary for the post-conflict reconciliation and reconstruction, including the lengthy process of statebuilding. The balance that fostered such stability and growth, however, has become uncertain when looking at the future of the Somaliland state. There is no doubt that the inclusion of the traditional authority was 
essential (see Walls and Kibble, 2010). Within Somaliland itself, this inclusion and the stability it fostered and facilitated is often credited with ensuring that Somaliland did not follow the same path as Somalia in the post-collapse era. The modern within Somaliland was not only unfamiliar but also outwardly exclusionary of clan politics within the democratic practices $;{ }^{28}$ even if only symbolic the Guurti allowed for the Somali population to identify with the new state structure and served as a buffering link between the new creation and the population. And as debates within Somaliland demonstrate, though, as the statebuilding process continues and as external demands increasingly become internal expectations, the Guurti is increasingly discussed in the language of the 'eternal yesterday.' As the new becomes more familiar and as political culture in Somaliland changes, the placement and role of the traditional will be tested with more frequency and intensity. However, these tests should not be seen as destabilising as Hashi warns, but rather must be viewed as a continuation of what has proven to be a flexible and responsive statebuilding process.

The Somaliland state has a significant amount of latitude in the exercise of sovereignty largely from the sovereign power that originated in the traditional authority. The inclusion of this institution in the state apparatus creates a level of central governance that not only resides within the government but also exists despite it. Theoretically, or more accurately symbolically, this has ensured that during periods of transition or in the event of a political crisis central governance could continue to exist through the traditional institution. In its place both within and above the government internally rooted sovereignty exercised by the traditional authority is extensible; the Guurti has the ability to fill the gaps when the government is weak, absent or vulnerable. This sovereign layer has added stability to the process, even if only through the provision of reassurance. In the hybrid negotiation, the founders of the new Somaliland state created an internal safety net for the government, the population and the overall project of the state. For Somaliland, the utilisation of the 'backwards' traditional authority was the best, and possibly only, option for the stabilisation of a contentious and potentially volatile environment during the period of extreme socio-political transition of postconflict statebuilding (Richards, 2012).

It is impossible to fully pinpoint exactly how or why the Guurti gained and maintained its legitimacy in the government and the statebuilding process, and it is possibly something a non-Somali cannot fully understand. The centrality of the clan system in terms of not only identity but also provision and governance made the elders an already existing mechanism of governance. Associations with the trusted and familiar governance that had long existed within Somaliland, and the work that the conflict and post-conflict era councils of elders did placed the Guurti within a position of trust and 
accessibility within Somaliland society. This certainly impacted upon its acceptance within the government and its power of legitimisation within centralised structures, and its continued presence in this unrecognised state demonstrates acceptance and legitimacy. However, as the state develops and the government evolves, the nature and function of the Guurti is also changing and the legitimacy it once held is being questioned. Indeed, as the negotiation between internal and external is changing and as external demands become part of the internal narrative, some argue that the Guurti is now a liability to stability rather than a benefit (see Hoehne 2013; Terlinden and Renders 2011; Renders 2012). As the statebuilding process continues, one of the mounting issues will be addressing the continued necessity of the hybrid government as it currently stands.

It is easy to view Somaliland through rose coloured lenses and to romanticise the Guurti. However, Somaliland is not perfect, and statebuilding in the territory has not been problem-free. Still undergoing the process of statebuilding, the Somaliland government itself is relatively weak as an institution. Its power does not extend far beyond the major cities and arguably much of Somaliland's non-urban population is 'untouched' by the government. Small coffers mean deficiencies in provision and this creates grievances and antagonistic feelings amongst some of the population. The government cannot claim control over the entirety of the former British Protectorate; the two eastern provinces of Sanaag and Sool are disputed territories, with much of the population there not recognising the legitimacy of Somaliland (ICG 2003). Contestation over these provinces is a constant point of friction and confrontation. Further, accusations of corruption and political infighting have stalled the statebuilding process on numerous occasions and constitutional ambiguity has created significant obstacles to be overcome (see Richards 2009; 2014). Government overstepping, particularly in the area of press freedom, has been a significant concern both within and outside of Somaliland. For some, the state apparatus is not meeting societal expectations of government, including its inability to obtain international recognition of sovereignty.

In less concrete terms, the state itself has changed and is often at odds with the narrative that has propelled the project thus far. The vision and narrative of what the state is and how it will function in relation to both domestic and international concerns has been altered from its original form to reflect changing circumstances in and around Somaliland. The internal dynamics impacting upon how the democratic component of the government can and will function have changed as democracy has been introduced and as the statebuilding process has progressed, creating tensions between those demanding modernisation and those preferring the status quo. The advantage of the Somaliland state, however, is that it can account for the flexibility needed to incorporate these obstacles and the 
necessary changes in a way that would not be assured if the process of creating a state had been directed or imposed from the outside. Because of inbuilt reconciliation mechanisms and an entrenchment of society in the state, potentially derailing obstacles have a chance to be resolved before they become catastrophic, and the state is allowed to be negotiated, to develop, and even to adapt. The Somaliland state is being fostered rather than imposed. This cannot be credited to just one component of the state or process: the creation of the Somaliland state has been a complex undertaking that has continued because of the work of many rather than just one. However, the inclusion of the council of elders in the government makes the Guurti not just an actor in the process, but is also indicative of the domestically-led and domestically-determined process itself.

Despite its obstacles, Somaliland has created a 'successful' state. Peace and stability have been maintained, democratic institutions have been established, free and fair democratic elections have been held, social goods have been provided, albeit minimally, and economic growth has been fostered and maintained. Somaliland is what Somalia should have become in the liberal vision guiding the ill-fated attempts at statebuilding there. More importantly, though, the Somaliland state is successful outside of the liberal context; it is a reminder that 'success' can be a subjective and incomplete assessment. The state in Somaliland is a complex and evolving political and social relationship between the political process and society. Much of this evolving relationship is driven by prospects for sovereign recognition and economic opportunity, but it is also reflective of what the people expect the state to be. The Somaliland state is successful not solely because it meets criteria outlined in the liberal framework, but also because it reflects the demands and expectations of society. It is not perfect, but no state is. Certainly there are areas where there are gaps between the state and societal expectations. However, because the state is a relationship rather than an imposition, there is not only the flexibility, but also the capability, to lessen the gap. As in any relationship, problems arise, but in the good relationships those problems are overcome. Somaliland has thus far shown that it is a solid relationship, and the expectation is that it will continue to evolve. Somaliland may have taken a different path to 'statehood,' but arguably it was the right one.

\section{Acknowledgments:}

This article in part is informed by field research undertaken in Somaliland as part of my $\mathrm{PhD}$ research. Thanks to the Academy for Peace and Development Hargiesa, Mohammed Hassan 'Gani' and Ulf Terlinden for their assistance in Hargeisa. Thanks also to Robert G. Smith and Mark Duffield for their feedback on earlier versions, and to the anonymous reviewers for their helpful suggestions for clarification and improvement.

\section{Notes}

${ }^{1}$ Whilst Somaliland will be discussed in the context of the state or statehood here, it must be noted that Somaliland exists as an 'unrecognised state' (Caspersen and Stansfield, 2011). It exhibits empirical statehood but lacks juridical statehood. 
Throughout this piece Somaliland is referred to as a 'state' and the social and political transformation taking place discussed in the context of 'statebuilding'. This is not done to create terminological or conceptual confusion, nor is it done in ignorance of Somaliland's lack of sovereign recognition or in any attempt to comment on that.

${ }^{2}$ As is frequently noted, when discussing the 'traditional' in the African state we must recognise the possibility of invented tradition. However, we must also recognise that even invented tradition can be accepted as 'traditional' by the people within society. For purposes here, the 'traditional' that is referred to is that which was identified and labelled by Somalilanders interviewed by the author. Further, the use of the term 'traditional' is done without connotation, normative judgements or any comment by the author on the often contentious use of the term.

${ }^{3}$ For a comprehensive overview, see Bradbury, 2008; Lewis, 2002; Renders, 2012; Drysdale, 2000.

${ }^{4}$ Interview with Hassan Issa, former Somaliland Vice President and former Vice Chairman of the Somali National Movement, September 2006, Hargeisa.

${ }^{5}$ Interview with Dr. Aden Abokor, Progressio Somaliland Country Representative, September 2006, Hargeisa.

${ }^{6}$ For more detailed explanations of the role of the clan and clan elders during the SNM campaign, see Lewis, 2002; Bradbury, 2008; Richards, 2009; Richards, 2014; Drysdale, 2000; Ford et. al., 2004; Renders, 2012.

${ }^{7}$ In contemporary Somali society, this traditional role is stronger and more intact in Somaliland than in Somalia itself. A number of factors, including experience of different styles of colonial rule as well as dominance of a single clan in Somaliland, contribute to the strength of clan governance in Somaliland.

${ }^{8}$ As the term guurti is used for both the traditional ad hoc council and the modern formal institution, for purposes here guurti will refer to or invoke the traditional or historical notion of the council of elders, whilst Guurti will refer to the council as a formal political institution.

9 This 'public relations' type activity is common for unrecognised states. For more discussion on this, see Caspersen, 2014.

${ }^{10}$ Various Interviews, members of government and civil society, August-October 2006, Hargeisa.

${ }^{11}$ Interview with Dr. Abdirahman Yusuf Artan, Member of Somaliland House of Representatives, September 2006, Hargeisa.

${ }^{12}$ Interview with Mohammed Hassan Ibrahim 'Gani', Researcher at Somaliland Academy for Peace and Development, August 2006, Hargeisa.

${ }^{13}$ Interview with Hassan Issa, former Somaliland Vice President and former Vice Chairman of the Somali National Movement, September 2006, Hargeisa.

${ }^{14}$ Interview with Mohammed Hassan Ibrahim 'Gani', Researcher at Somaliland Academy for Peace and Development, August 2006, Hargeisa.

${ }^{15}$ Interview with Mohammed Said Gees, Executive Director of the Somaliland Academy for Peace and Development and former Government Minister, October 2006, Hargeisa. See also Walls 2008.

${ }^{16}$ Interview with Hassan Issa, former Somaliland Vice President and former Vice Chairman of the Somali National Movement, September 2006, Hargeisa.

${ }^{17}$ Interview with Haji Abdi Husein, Chairman of the Standing Committee of the Somaliland House of Elders, August 2006, Hargeisa.

${ }^{18}$ Interview with Mohamme Said Gees, Executive Director of the Somaliland Academy for Peace and Development and former Government Minister, October 2006, Hargeisa.

${ }^{19}$ Interview with Abdirahman Aw Ali Farah, former Vice President and former SNM Commander, September 2006, Hargeisa.

${ }^{20}$ Interview with Abdullahi Duali, Minister of Foreign Affairs, September 2006, Hargeisa.

${ }^{21}$ Interview with Haji Abdi Husein, Chairman of the Standing Committee of the Somaliland House of Elders, September 2006, Hargeisa.

${ }^{22}$ Interview with Abdirahman Aw Ali Farah, former Vice President and former SNM Commander, September 2006, Hargeisa.

${ }^{23}$ Interview with Ahmed Yusuf Yassin, Vice President of Somaliland, September 2006, Hargeisa.

${ }^{24}$ Interview with Abdikadir Mohammed Hassan 'Indho', Committee Chairman in the Somaliland House of Elders, August 2006, Hargeisa.

${ }^{25}$ Interview with Hassan Issa, former Somaliland Vice President and former Vice Chairman of the Somali National Movement, September 2006, Hargeisa.

${ }^{26}$ Interview with Haji Abdi Husein, Chairman of the Standing Committee of the Somaliland House of Elders, September 2006, Hargeisa.

${ }^{27}$ Interview with Mohammed Said Gees, Executive Director of the Somaliland Academy for Peace and Development and former Government Minister, October 2006, London.

${ }^{28}$ The Constitution of Somaliland allows for the existence of only three political parties at any given time within the territory. These parties cannot be clan-based. The inclusion of this Constitutional clause is a direct reaction to the clanbased political system of Somalia from 1960-1969. 


\section{References}

Adamson, F. 2006. "National Polities and Global Ideologies: Political Mobilisation Beyond the State." Paper presented at the PSA Workshop on Ethical Norms, Political Agency and the State, Sheffield, November 10.

Bradbury, M. 1997. Somaliland Country Report. London: Catholic Institute for International Relations.

Bradbury, M. 2008. Becoming Somaliland. Oxford: James Currey.

Bradbury, M. 2010. "Ethnicity and the Emergence of Somaliland." In: The Ethnicity Reader: Nationalism, Multiculturalism and Migration, edited by M. Guibernau and J. Rex, 125-134. Cambridge: Polity.

Brownlie, I. 1998. Principles of Public International Law. $5^{\text {th }}$ ed. Oxford: Clarendon Press.

Bruton, B. 2010. "Somalia: A New Approach.” Council on Foreign Relations Special Report No. 52.

Bryden, M. 1999. "New Hope for Somalia? The Building Block Approach.” Review of African Political Economy 26 (79): 134-140.

Bryden, M. 2003. "The Banana Test: Is Somaliland ready for recognition?” Annales d'Éthiopie 19: 341-364.

Call, C. and V. Wyeth, eds. 2008. Building States to Build Peace. London: Lynne Rienner.

Caspersen, N. and G. Stansfield. 2011. "Introduction." In: Unrecognised States in the International System, edited by N. Caspersen and G. Stansfield, 1-8. London: Routledge.

Caspersen, N. 2012. Unrecognised States: The Struggle for Sovereignty in the Modern International System. Cambridge: Polity.

Caspersen, N. 2014. "The Politics of Getting Online in Countries that Don't Exist." The Conversation, January 14. Available at http://theconversation.com/the-politics-of-getting-online-incountries-that-dont-exist-21399 [Last accessed 14 January 2014].

Chandler, D. 2010. International Statebuilding: The Rise of Post-Liberal Governance. London: Routledge.

Chesterman, S., Ignatieff, M and R. Thakur. 2005 "Making States Work." In: Making States Work: State Failure and the Crisis of Governance, edited by S. Chesterman, et al, 1-10. Washington DC: Brookings Institution Press.

Daase, C., Geis, A. and G. Kolliarakis, eds. 2015. Recognition in International Relations: Rethinking an Ambivalent Concept in a Global Context. London: Palgrave.

Dobbins, J., et al. 2003. America's Role in Nation-Building From Germany to Iraq. Santa Monica, CA: RAND Corporation. 
Dobbins, J., et al. 2005. The UN's Role in Nation Building: From Congo to Iraq. Santa Monica, CA: RAND Corporation.

Dowden, R. "Don't Force Statehood on Somalia." African Arguments. Available at http://africanarguments.org/2011/10/20/don\%E2\%80\%99t-force-statehood-on-somalia-by-richarddowden/.

Drysdale, J. 2000. Stoics Without Pillows: A Way Forward for the Somalilands. London: HAAN Associates.

Finnemore, M. 1996. National Interests in International Society. Ithaca: Cornell University Press.

Finnemore, M. and K. Sikkink. 1998. "International Norm Dynamics and Political Change." International Organization 52 (4): 887-917.

Ford, R., Adam, H., and E. Ismail, eds. 2003. War Destroys, Peace Nurtures: Reconciliation and Development in Somalia. Lawrenceville, NJ: Red Sea Press.

Fukuyama, F. 2006. Nation-Building: Beyond Afghanistan and Iraq. Baltimore: The Johns Hopkins University Press.

Ghani, A. and C. Lockhart. 2005. ODI Working Paper 253: Closing the Sovereignty Gap: An Approach to Statebuilding. ODI: London.

Ghani, A. and C. Lockhart. 2008. Fixing Failed States: A Framework for Rebuilding a Fractured World. Oxford: Oxford University Press.

Gourevitch, A. 2004. “The Unfailing of the State.” Journal of International Affairs 58 (1): 255-260.

Halden, P. 2008. “Somalia: Failed State or Nascent States-System?” FOI Somalia Papers: Report 1.

Hashi, A. 2005. The Implications of Traditional Leadership, 'Guurti' and Other Non-State Actors in Local Governance in Somaliland. World Bank Community Empowerment and Social Inclusion Programme Report.

Herbst, J. 2000. States and Power in Africa: Comparative Lessons in Authority and Control. Princeton: Princeton University Press.

Hohne, M. 2006. Working Paper 82: Traditional Authorities in Northern Somalia: Transformation of Positions and Power. Munich: Max Planck Institute for Social Anthropology.

Hohne, M. 2013. "Limits of Hybrid Political Orders: The case of Somaliland." Journal of Eastern African Studies 7 (2): 199-217.

Hohne, M. and M. Ibrahim. 2014. "Rebuilding Somaliland through economic and educational engagement." In: Diasporas, Development and Peacemaking in the Horn of Africa, edited by L. Laakso and P. Hautaniemi, 53-76. London: Zed Books.

International Crisis Group. 2003. Somaliland: Democratisation and its Discontents. Nairobi/Brussels: ICG. 
Jackson, R. 1990. Quasi-States: Sovereignty, International Relations and the Third World. Cambridge: Cambridge University Press.

Kolsto, P. 2006. "The Sustainability and Future of Unrecognized Quasi-States.” Journal of Peace Research 46 (3): 723-740.

Lewis, I.M. 1994. Blood and Bone: The Call of Kinship in Somali Society. Lawrenceville, NJ: The Red Sea Press.

Lewis, I.M. 2002. A Modern History of the Somali. Oxford: James Currey.

Lewis, I.M. and A. Farah. 1997. "Peace Making Endeavors of Contemporary Lineage Leaders in Somaliland." In: Mending the Rips in the Sky: Options for the Somali Communities in the $21^{\text {st }}$ Century, edited by H. Adam and R. Ford, 317-326. Lawrenceville, NJ: The Red Sea Press.

Lindley, A. 2005. Somalia Country Study. Oxford: COMPAS Report on Informal Remittance Systems in African, Caribbean and Pacific Countries.

Menkhaus, K. 2007. "Governance without Government in Somalia: Spoilers, State Building, and the Politics of Coping." International Security 31 (3): 74-106.

Milliken, J (ed). 2003. State Failure, Collapse and Reconstruction. Oxford: Blackwell.

Mosley, J. 2012. "End of the Roadmap: Somalia after the London and Istanbul Conferences." Chatham House Africa Programme Paper AFP PP2012/04.

Paris, R. and T. Sisk (eds). 2009. The Dilemmas of Statebuilding: Confronting the Contradictions of Postwar Peace Operations. London: Routledge.

Pham, J. 2011. "Somalia: Where a State Isn't a State.” The Fletcher Forum of World Affairs 35 (2): 133-151.

Renders, M. 2012. Consider Somaliland: Statebuilding with Traditional Leaders and Institutions. Leiden: Brill.

Richards, R. 2009. Building the Ideal: Traditional Governance and the Modern State in Somaliland. PhD Thesis, University of Bristol.

Richards, R. 2012. "The Road Less Travelled: Self-Led Statebuilding and International NonIntervention in the Creation of Somaliland." In: Statebuilding and State-Formation: The Political Sociology of Intervention, edited by B. Bliesemann de Guevara, 149-164. London: Routledge.

Richards, R. 2014. Understanding Statebuilding: Traditional Governance and the Modern State in Somaliland. Farnham: Ashgate.

Rotberg, R. 2003. "Failed States, Collapsed States, Weak States: Causes and Indicators." In: State Failure and State Weakness in a Time of Terror, edited by R. Rotberg, 1-28. Washington DC:

Brookings Institution Press. 
Samatar, I. 1997. "Light at the End of the Tunnel: Some Reflections on the Struggle of the Somali National Movement." In: Mending the Rips in the Sky: Options for the Somali Communities in the $21^{\text {st }}$ Century, edited by H. Adam and R. Ford, 21-38. Lawrenceville, NJ: The Red Sea Press.

Samatar, A. 1989. The State and Rural Transformation in Northern Somalia, 1884-1986. Madison: University of Wisconsin Press.

Shils, E. 1995. "Nation, Nationality, Nationalism and Civil Society." Nations and Nationalism 1(1): 93-118.

Shils, E. 2006. Tradition. Chicago: University of Chicago Press.

Shivakumar, S. 2003. "The Place of Indigenous Institutions in Constitutional Order." Constitutional Political Economy 14 (1): 3-21.

Sisk, T. 2013. Statebuilding. Cambridge: Polity.

Spears, I. 2004. "Reflections on Somaliland and Africa's Territorial Order." In: War Destroys, Peace Nurtures: Somali Reconciliation and Development, edited by H. Adam, et al, 179-192.

Lawrenceville, NJ: The Red Sea Press.

Sweden, J. 2004. "Somaliland's Quest for Recognition: A Challenge for the International Community." In: War Destroys, Peace Nurtures: Reconciliation and Development in Somaliland, edited by H. Adam, et al, 169-178. Lawrenceville, NJ: The Red Sea Press.

Terlinden, U. and M. Renders. 2011. "Negotiating Statehood in a Hybrid Political Order: The Case of Somaliland." Development and Change 41 (4): 723-746.

Walls, M. 2008. Peace in Somaliland: An Indigenous Approach to State-Building. Hargeisa/Nairobi: Interpeace/APD Somali Programme Search for Peace Report.

Walls, M. 2009. "The Emergence of a Somali State: Building peace from civil war in Somaliland." African Affairs 108 (432): 371-389.

Walls, M. and S. Kibble. 2010. "Beyond Polarity: Negotiating a Hybrid State in Somaliland." Africa Spectrum 45 (1): 31-56.

Weber, M. 1967. "Politics and Vocation." In: From Max Weber: Essays in Sociology, edited by H. Gerth and C. Wright Mills, 77-128. London: Routledge.

WSP-International. 2003. "Facilitating Somaliland's Democratic Transition.” Dialogue for Peace Somali Programme Report.

WSP International. 2005. Rebuilding Somaliland: Issues and Possibilities. Lawrenceville, NJ: The Red Sea Press.

WSP-International. 2006. "Local Solutions: Creating an Enabling Environment for Decentralisation in Somaliland." Dialogue for Peace Somali Programme Report. 
WSP-International. 2012. "A Vote for Peace II: A Report on the 2010 Somaliland Presidential Election Process.” Dialogue for Peace Somali Programme Report. 